\title{
Students' Power Relationships within an EFL Classroom
}

\section{Relaciones de poder de los estudiantes dentro de un aula donde se enseña inglés como lengua extranjera ${ }^{1}$.}

\author{
Lila Maribel Gutiérrez Pulido² \\ lilamar27@yahoo.es \\ Institución Educativa Colegio Sugamuxi
}

Received: Semptember 15, 2015

Accepted: December 15, 2015

How to cite this article (APA, 6th ed.): Gutierrez, L. (2016). Students' power relationships within an EFL classroom. Enletawa Journal, 9 (1), 33-51

\begin{abstract}
This paper reports the results of a research study whose main purpose was to identify aspects related to power relationships in a group of ninth-grade English learners. An EFL classroom was used as the setting to analyze power relationships among students. A qualitative case study was carried out in a public school from Sogamoso; the participants were 8 students, selected at random from a group of 35 . The data was gathered through field notes, video recordings and focused interviews. After analyzing the data, it was found that aspects connected to power relationships sometimes either helped or hindered the participants' English language learning process. Positive and negative features concerning power relationships within the EFL classroom were identified. Positive features include the use of power to

1 Research Report

2 Holds a B.A. in Modern Languages English and Spanish form Universidad Pedagógica y Tecnológica de Colombia (UPTC). She is an M.A. candidate in Language Teaching from the same University. She has taught English as a Foreign Language for about eleven years. She holds Band 4 in the Teaching Knowledge Test from University of Cambridge. Currently, she works as a full time teacher in a public school from Sogamoso, Boyacá.
\end{abstract}


motivate the accomplishment of tasks. Negative features include the use of power to suppress others thereby limiting their ability to express opinions in class.

Key Words: Power, Power Relationships, Task Based Language Learning, Classroom Environment, English Language Learning Process.

\section{Resumen}

Este artículo reporta los resultados de un estudio de investigación cuyo propósito principal era identificar aspectos relacionados con las relaciones de poder en un grupo de estudiantes de noveno grado que estaban aprendiendo inglés. Se tomó un aula donde se enseñaba inglés como lengua extranjera como escenario para analizar las relaciones de poder entre estudiantes. Un estudio de caso cualitativo se llevó a cabo en un colegio público de Sogamoso. Los participantes fueron 8 estudiantes seleccionados al azar de un grupo de 35. Los datos se recolectaron a través de notas de campo, video grabaciones y entrevistas focalizadas. Después de analizar los datos, se encontró que aspectos relacionados con relaciones de poder algunas veces ayudaron y otras veces obstruyeron el proceso de aprendizaje de los participantes. Se identificaron características positivas y negativas con respecto a las relaciones de poder dentro del aula. Las positivas incluyen el uso de poder para motivar al cumplimiento de tareas. Las negativas incluyen el uso de poder para suprimir a los demás, lo que limita su capacidad para expresar sus opiniones en clase.

Palabras Clave: Poder, Relaciones de poder, Aprendizaje de idiomas basado en tareas, Ambiente del aula, Proceso de aprendizaje del Idioma inglés.

\section{Introduction}

Although children and youth have sometimes been victims of different aggressions from their peers at school since ancient times, just since a few years ago people have begun to be aware of the harm that some students' behaviors against others can cause. For that reason, schools and people enrolled in the education field started to worry about this problem. At present, it is crucial that schools provide an adequate learning environment where all students feel safe in a community in which students' differences and rights are respected.

The government, more specifically the Ministry of Education, created a law to strengthen and promote the fulfillment of learners' rights within and outside the classroom, “Ley 1620, 15 de marzo de 2013” (Law 1620, 15 March 2013), which establishes some regulations for educational settings in Colombia concerning the school climate, school violence, human rights and education on sexuality. According to this law, schools have to undertake actions to prevent any kind of risk 
that endangers the normal development of schoolchildren and generates an adequate climate in which learners feel comfortable.

The considerations previously mentioned and the analysis of the Institutional and Educational Project of the school, where the research took place, concerning the institutional goals for the year 2016, motivated the researcher to explore power relationships among students in the EFL classroom. Consequently, a needs analysis was carried out which led the researcher to notice that the English languagelearning process was in some way being affected by the power relationships students manifested within the classroom.

After an observation process and the application of a survey whose purpose was to inquire about the students' perceptions in relation to school coexistence, it was possible to notice that there were some aspects related to power relationships that emerged as a real need to be researched and improved through the day-to-day pedagogical exercise within the classroom.

In this sense, the study intended to explore what aspects related to power relationships could be evidenced and inferred from a group of ninth-grade English learners, as well as, what situations of the English language learning process were affected by power relationships in the EFL classroom. Students were involved in group task- based activities in order to see what kinds of attitudes they assumed in front of their classmates' opinions during the procedures they had to carry out for completing the task. As Maxwell (2009) states, teamwork requires discussion and agreements among students. It could be observed how students behaved within the group, how they presented and defended their positions and if they heard, respected and accepted others' points of view.

In the next sections of the article the reader will find first, some important theoretical constructs that supported the research. Second, the instructional methodology which explains the peda-gogical intervention of the project and the research design which includes specific information about the type of research, type of study, setting, participants, and data collection instruments. Finally, the findings, conclusions, pedagogical implications, further research and limitations of the study conducted are presented.

\section{Theoretical Background}

Three main constructs were relevant to carrying out the study first being, the concept of power and some of its connotations in the educational field. Second construct involves some remarkable considerations about power relationships and the third some important issues related to classroom environment. 


\section{Power.}

Power is a broad term that widely applies to different political, economic, and social fields and it entails a range of perspectives which vary according to the contexts and groups of individuals who interact in those contexts. According to Brown and Gilman (1960), one person may be said to have power over another in the degree that he is able to control the behavior of the other. Power is a relationship between at least two persons, and it is nonreciprocal in the sense that both cannot have power in the same area of behavior. In this sense, power is unidirectional because someone directly or indirectly controls the behavior of someone else depending on the situation and the strengths the individual who exerts power has in relation to the one who is controlled.

Power, according to Foucault (1994), is something that circulates and is produced from one moment to another as part of the relationships human beings construct. Ortega (2005) affirms that power is a relational phenomenon, since social power is necessarily a bilateral quality of the relationships between an agent and a target.

Within the educational field, power is an existent phenomenon which is presented due to the continuous interaction among the individuals that coexist in a classroom. Ramos (2004) states that power in the educational context has been studied by different authors who have evidenced its importance not only within a particular community but also in any place in which interaction occurs. The classroom is a focus of research because of the great amount of interactions that take place among students. Classrooms are communication contexts in which learners meet and share a series of experiences, knowledge, feelings and many more issues that are inherent to students as human beings.

\section{Types of Power.}

The types of power have been classified by different authors according to the source they come from, the ways in which each kind of power is exercised and the intention an individual has when exerting power over another individual. One of the most recognized studies about this topic was conducted by French and Raven (1959). They identified five types of power: Coercive, reward, legitimate, referent, and expert.

Legitimate: This comes from the belief that a person has the formal right to make demands, and to expect compliance and obedience from others. Legitimate power comes from an elected, selected, or appointed position of authority and may be underpinned by social norms. Reward: This results from one person's ability to compensate another for compliance. Reward power is based on the right of someone to offer tangible, social, emotional, or spiritual rewards to others for doing what is wanted or expected of them, or conversely, to deny others something for failing to or refusing to do what is 
desired or expected of them. Expert: This is based on a person's superior skill and knowledge. When individuals perceive or assume that a person possesses superior skills or abilities, they award power to that person. Expert power is based on what one knows, experience, and special skills or talents. Referent: This is the result of a person's perceived attractiveness, worthiness, and right to demand respect from others. Referent power is rooted in the affiliations we make and/or the groups and organizations we belong to, our affiliation with a group and the group's beliefs are shared to some degree. Use of this power base and its outcomes may be negative or positive. Coercive: This comes from the belief that a person can punish others for noncompliance. Coercive power uses the threat of force to gain compliance from another. Force may include physical, social, emotional, political, or economic means. Coercion is not always recognized by the target of influence. The main idea behind this concept is that someone is forced to do something that he/she does not desire to do or is prevented from doing something that he/ she would normally do.

Another remarkable typification of power was the one made by Cummins (2000), who distinguishes two kinds of power relationships: Coercive and Collaborative. Coercive power allows for the imposition of oppression, abuse, inequity and totalitarianism. Coercive relations of power refer to the exercise of power by a dominant individual, group or country to the detriment of a subordinated individual, group or country. Collaborative power, on the other hand, affords a community democratic expression, human rights and freedom. Collaborative relations of power reflect the sense of the term 'power' that refers to 'being enabled' or 'empowered' to achieve more.

\section{Power Relationships.}

Power relationships are inherent to human relationships; individuals within a community establish connections, discuss making decisions and interact constantly generating a set of relationships in which there is always some who control and others who are controlled according to the situations and contexts where the interactions take place.

When those power relationships are seen and analyzed within the context of a classroom, some remarkable aspects have to be considered, such as the conditions under which the students come to class, what they have done, what they already know, what they are expected to learn, what they really want to learn and the way they put all these things together when they interrelate with their peers.

Foucault (1977) states that power relationships are not constant but always in motion, implying that we create power as we engage in relationships and that at times that power shapes our own actions. 
Classrooms are social environments in which different individuals with diverse personalities and a wide range of abilities come together to create a complex web of human relationships. Within the context of social interactions, some students may have more power and influence over other learners.

Power relationships among students are present thanks to the interactions that emerge in the classroom. Those interactions are facilitated because the teacher provides students with the possibility to express themselves. Thus, power is constructed rather than imposed, as stated by Ramos (2004). In the present study, the teacher gave students the opportunity to work in groups to accomplish some tasks, so they had to get together, discuss and make decisions. Those decisions were frequently made by students who somehow exercise influence over the others.

Power relationships also have to do with agreements and disagreements present in class. According to Toohey (2001), agreements and disagreements are a means of negotiation of meaning and power positions among participants. Toohey (2001) examined the way children use disagreements about decision-making activities as a tool for the construction of their personality in terms of ideas, knowledge, and leadership. Power relationships can not only be the source of conflicts, but also a way to give students the opportunity to exercise leadership and to generate discussions in order to make decisions collectively with the purpose of achieving common goals. Rosemary (2004) supports this idea by asserting that students can strategically be assigned to work collaboratively in small groups and afforded the opportunity to share their views with classmates in supervised discussions.

\section{Classroom Environment.}

Wilson (1996) asserts that a classroom learning environment has traditionally referred to a space where learners and teachers met to interact with each other and use a variety of tools and information resources in their pursuit of learning outcomes. As this concept has evolved, the type of relations constructed between teachersstudents and among students have also changed and evolved. Richmond and McCroskey (1992) expose another view. They show that the classroom as a place where invisible battles for power take place, and in this case, these conflicts may affect, at a high or a low degree, the vital learning experience in classrooms.

Johnson (1979) asserts that a classroom is a social system that is made up by a network of interpersonal relationships structured to facilitate the achievement of educational goals. However, this does not happen when students do not establish good power relationships and do not use power democratically. 
After stating the theoretical basis of the study, the following lines expose the relationship between the main concern of this research, power relationships, and the pedagogical intervention applied to the target group. What the pedagogical proposal consisted of and the intention and the role of the proposal within the study is also described.

\section{Instructional Methodology}

This study focused on the power relationships among students within the EFL classroom, how those relationships were established and how they helped or hindered the English learning process. Bearing in mind the focus of the study, the pedagogical intervention was designed in order to get students interacting and establishing different kinds of relationships. Thus, taskbased language learning was selected as the framework of this part of the study, given that when students work to accomplish a task they have to give and receive ideas, make agreements, discuss how they will complete the task and finally make decisions in order to get good results. Task-Based Language Learning involves interaction and negotiation. Long (1983) underscores the fact that a task needs to include a negotiation of meaning in order to effectively propel language acquisition forward.

The pedagogical strategy developed in this study consisted of six workshops which included the three phases of task-based language learning proposed by Ellis (2003) in his framework for designing task-based Lessons: pre- task, task and post-task. According to this author; in the pre-task phase, the activity is framed, there is an introduction to the topic, the teachers gives clear instructions on what students will have to do and sometimes the teacher recalls some language that may be useful for accomplishing the task. During the task phase, the students perform the task, typically in small groups or pairs. In the post-task phase students report the task they have completed or complement it by carrying out an activity focused on communication.

The work sessions of this pedagogical proposal were planned to carry out a pre-task with the whole group, a task in small groups or pairs and a post-task in which students intervene individually or collectively in front of the whole group. The workshops designed for this pedagogical intervention encompassed the title, the topic, the goal, the resources and the description of the pre-task, task and post-task for each one of the work sessions. There was also an excerpt in which the research focus for each one of the activities was explained.

The topics of the first three workshops were chosen taking into account the syllabus of the school which encompasses issues related to healthy habits, suitable use of technology and care of the environment as part of some transversal projects the institution carries out. The topics of the last three workshops were directly related with 
the area of the study; students were asked to reflect, through the tasks, about some topics which have to do with power relationships and classroom coexistence, such as bullying, respect and emotional intelligence.

The pedagogical proposal was the foundation for finding out aspects related to power relationships and giving students the opportunity to reflect on topics related to school and classroom coexistence, as well as, proposing some strategies in order to improve the environment where classes were carried out and consequently to develop a more effective English language learning process.

\section{Research Design.}

Qualitative research was used in this study, given that it intended to analyze a real context focusing on some participants who interacted and were immersed in a particular social and cultural environment, each one with their own attitudes and behaviors. Brown and Rodgers (2002) state that it is a kind of research that includes various different non-numerical techniques for gathering data such as observations/ field notes, diaries, questionnaires, interviews, etc. Taking into account the objectives and the focus of this research, this study can be considered a qualitative case study. As Yin (2009) explains, this type of investigation takes the researcher to a process in which he may collect the specific and general characteristics and details of real life events such as group behavior. One of the main objectives of this research was to find out and analyze information from the participants in a real and specific context in order to develop a description of the aspects related to power relationships which were present in the classroom, and based on that description to be able to determine how those aspects influenced the language learning process in that specific group of participants.

\section{Setting and Participants.}

This study took place at a public school in Sogamoso, which was founded 110 years ago. It offers education to students from pre-school to eleventh grade. At present, 2180 are registered in the school. Most students in the school belong to strata 1, 2 and 3 .

There were five ninth-grade groups in the school and this teacher-researcher guided English classes in two of them. The target group was "9E", and from the whole group eight students were selected at random as the participants of the study. These students were between 14 and 17 years old.

\section{Data Collection Instruments.}

The instruments used to collect the data were field notes, video recordings and focused group interviews. Field notes were written based on direct observation and the video recordings were a support for writing a more detailed description of what was happening in the classroom. The videos 
were not transcribed and the researcher used the videos to nourish the field notes with specifics facts that she did not remember well at the moment of writing. The focused interviews were carried out with the group of participant students.

Next, the author describes the analysis of the data gathered throughout the application of these workshops which were the pretext for identifying the aspects related to power relationships and its influence on the students' English learning process.

\section{Findings}

The procedures and techniques from grounded theory (Corbin and Strauss, 1990) were applied to data analysis process. The first step in this process was to read the data from the field notes, video recordings and focused interviews and analyze them using an open coding system. During open coding, the data were broken down into discrete parts, closely examined and compared for similarities and differences. A color system was used to codify the data, which consists of assigning a different color to data with similar or common patterns. After open coding axial coding is the next step. This type of coding consists of putting the data back together again but in a new way so as to make connections and finally categorizing data, which is defined as the process of grouping concepts that seem to pertain to the same phenomena.

After this process, an analysis of the similarities among those issues was done and some categories emerged. Then some of those first categories were linked together and became one or converted in a subcategory and finally four categories and three sub-categories resulted.

The category, High self-confidence leads to others' attention, resulted from the finding that students with high self-confidence always got their classmates attention; they showed themselves as powerful in front of their peers and exercised leadership in different activities and processes within the classroom. On the contrary students who evidenced a low selfconfidence level were the ones who did not participate, were always silent and preferred that other students took the floor in class. Students with high self-confidence manifested this characteristic through their tone of voice and their constant participation in class. Here we have an excerpt that is an exemplification of the contrast between students who talked with selfconfidence and students who did not like to speak in front of the class. This is an excerpt of the field notes taken in the first work section. 
(Chart 1 taken from the field notes)

\begin{tabular}{|c|c|}
\hline Description & Researcher Analysis \\
\hline $\begin{array}{l}\text { February } 8^{\text {th }} \text {-2016 } \\
\text { The teacher starts the class by asking some intro- } \\
\text { ductory questions: } \\
\text { - Did you have breakfast this morning? } \\
\text { - What did you have? } \\
\text { - Do you eat vegetables? Do you like them? } \\
\text { - Do you eat junk food? } \\
\text { - Do you normally do exercise? How often? } \\
\text { Some students are afraid of participating, but } \\
\text { some others talk without any problem, } 11 \text { students } \\
\text { participate in this part of the class, some of them } \\
\text { two or three times. } \\
\text { The teacher introduces a video, students watch the } \\
\text { video and then there is a discussion in which the } \\
\text { teacher elicits information about the contents of } \\
\text { the video. Several students participate in this part } \\
\text { and } 7 \text { of them had already participated in the first } \\
\text { part of the class. Teacher asks students to think } \\
\text { about some healthy and unhealthy habits and } \\
\text { share them with the class. } 10 \text { students participated } \\
\text { in this part and } 7 \text { of them had already participated } \\
\text { in the first and second part of the class. }\end{array}$ & $\begin{array}{l}\text { From the group of students who } \\
\text { participated in these parts of the } \\
\text { class, six are my participants, they } \\
\text { participated actively, several times, } \\
\text { and they were kind of confident and } \\
\text { talked without any problem. I could } \\
\text { notice that the other two participant } \\
\text { students were afraid to talk and } \\
\text { showed low interest in taking the } \\
\text { floor. These aspects were evidenced } \\
\text { because of their attitudes when } \\
\text { speaking. Meanwhile the former } \\
\text { were spontaneous and energetic; } \\
\text { the last ones were silent. }\end{array}$ \\
\hline
\end{tabular}

Two subcategories arose from this category: The tone of voice as a source of power and when I know I feel powerful. The former subcategory has to do with what Tannen (1995) calls linguistic style: Everything that is said must be said in a certain way, in a certain tone of voice, at a certain rate of speed, and with a certain degree of loudness. Whereas often we consciously consider what to say before speaking, we rarely think about how to say it. Communication is not as simple as saying what you mean. How you say what you mean is crucial, otherwise what you want to convey would not have any impact on the receiver. From the data gathered, it was possible to notice how the tone of voice reflected high or low self-confidence and made some students seem more powerful than others. When the teacher asked a question to the whole group, those students who felt more powerful were the ones who answered in a loud voice. On the contrary, the students who did not speak or spoke softly did not feel confident and seemed to be less powerful within the group. This is exemplified in the following Verbatim:

\section{Verbatim (video third session):}

T: Ok...look at these pictures and tell me what are they about? What are these pictures about? 
Falcao: antes y después... [before and after...]

Clarita: de la tierra antes y después o ahora cuando está contaminada... [from the earth before and after or know when is contaminated]

James: antes y después... [before and after...]

T: yes, good...our earth before, as you can see, there were a lot of green zones and beautiful landscapes and after...after contamination...

Falcao: muchas fábricas y basura... [lots of factories and garbage]

T: yes, because of the factories, what else?

Pamela: porque nosotros mismos contaminamos. [because we pollute ourselves]

T: so, what should we do and shouldn't do to avoid contamination?

Falcao: no botar basuras... [do not litter]

Pepita: no desperdiciar agua... [do not waste water]

Clarita: no contaminar los ríos... [do not contaminate rivers]

Falcao: $y$ reciclar... [and recycle]

T: very good, recycle...recycle at home, at school and do not throw garbage on the floor, neither in the streets or rivers. And how do you say that in English?

Juanes: we should recycle.

James: we should recycle? (Doubting and with a low tone of voice).

(The teacher repeats the phrase correcting pronunciation).

As several students talked at the same time, the students whose voices were louder were the ones heard by the rest of the class and their opinions were the ones that the teacher heard and referred to in order to continue the class.

The second subcategory, when I know I feel powerful, deals with the fact that knowledge gives power. French and Raven (1959) identified the Expert power which is based on a person's superior skill and knowledge. When individuals perceive or assume that a person possesses superior skills or abilities, they award power to that person. Most of the times students who had a higher English level were the ones who controlled the class, however other students in spite of their low English level, took the floor and participated in Spanish because they knew about the class topic and they felt they could contribute, be active and give their opinions based on their knowledge about it.

The second category, what I am in a group affects how others interact with me, indicated that the role and the image each student had within the group affected the others' reaction in front of him/her. Students who had a positive image, who played an important role within the group and who could be considered "wanted" by the group were the most heard and respected when they took the floor. On the contrary, students who had a negative image, who had acquired a disagreeable role with the group and hence they could be considered "unwanted" by the group, were not listened to and disrespected by others when they talked. The next excerpt shows a reflection from the researcher which focuses on the participation level of students with positive and negative image in front of the group. 
(Excerpt $\mathrm{N}^{\circ}$ 04. - Field Notes)

\begin{tabular}{|c|c|}
\hline Description & Researcher Analysis \\
\hline $\begin{array}{l}\text { March } 7^{\text {th }} \text {-2016 } \\
\text { Several students participate by giving their } \\
\text { opinions about the topic and answering the } \\
\text { questions suggested by the teacher. } \\
\text { Students who participate in this part of the } \\
\text { class are the ones who always participate; } \\
\text { they are the leaders of the group and the rest } \\
\text { of the students, respect and support their } \\
\text { opinions. } \\
\text { One student who does not participate com- } \\
\text { monly takes the word and expresses his point } \\
\text { of view about the topic, in opposition to what } \\
\text { the main leader of the group had said, and } \\
\text { immediately, the class goes against him and } \\
\text { does not allow him to finish his intervention. } \\
\text { He has no option but to remain silent. }\end{array}$ & $\begin{array}{l}\text { In this part I could notice that depend- } \\
\text { ing on the image each student has in the } \\
\text { group, his/her opinions are valued or re- } \\
\text { jected, the students who are the leaders } \\
\text { and have a positive image in the group } \\
\text { are the ones who always participate be- } \\
\text { cause they know that their opinions are } \\
\text { not going to be refused, on the contrary } \\
\text { students whose image is quite negative, } \\
\text { those who are isolated and those who are } \\
\text { not recognized within the group almost } \\
\text { never participate because they are not } \\
\text { sure if their opinions will be accepted of } \\
\text { not. }\end{array}$ \\
\hline
\end{tabular}

Another example shows an their opinions about the topic and their important reflection after the pre-task activity on session five, it consisted of a brainstorming activity based on a video about respect. Students were aware of the importance of this topic regarding the improvement of classroom coexistence. So, they gave interventions were very constructive. One of them referred to the fact that being respected depended upon the role each student played within the group and the positive or negative image he/she had.

(Excerpt $\mathrm{N}^{\circ}$ 17. - Field Notes)

\begin{tabular}{|c|c|}
\hline Description & Researcher Analysis \\
\hline $\begin{array}{l}\text { March } 11^{\text {th }}-2016 \\
\text { Students watch a video about re- } \\
\text { spect. The video gets their attention } \\
\text { and they were focused on it. } \\
\text { Teacher elicits information about } \\
\text { students' concept of respect based } \\
\text { on the video. Most students actively } \\
\text { participate after the video; however, } \\
\text { the students who always remain si- } \\
\text { lent, again remain silent. }\end{array}$ & $\begin{array}{l}\text { One of my participant students (Juanita) said that } \\
\text { the conflicts within the group were present because } \\
\text { some classmates were more respected than others. } \\
\text { She believed that students were judged by how they } \\
\text { were seen in the group, some of them had acquired } \\
\text { an important role within the group and they were } \\
\text { respected by the class, on the contrary other class- } \\
\text { mates were seen as weak students, so they were an } \\
\text { easy target to be attacked. }\end{array}$ \\
\hline
\end{tabular}

The former examples show how students interacted and behaved towards other students depending on the image that the group has about each student. Those students whose image was positive exercised what French and 
Raven (1959) identify as legitimate power. They had reached a position which allowed them to make demands and expect obedience from others. On the contrary, those students whose image was negative were not respected by the group and their opinions were not as valuable as others students' opinions.

From this category, a subcategory called Controller vs. Controlled Students arose. During the data collection and analysis process, two types of students were identified by the researcher. The ones who led the processes, who participated more and who were followed by the others, she named the "controller" students. While she identified those students who almost never participated, did not lead processes and who followed other classmates, as the "controlled" students. Most of the students within the classroom were aware of what group they belonged to, and for that reason they behaved spontaneously or diffidently. Some of them showed themselves very confident and powerful because they knew they were the "controller" and some others stopped themselves of participating or doing some things because they intrinsically knew they were the "controlled".

These two types of learners, identified by the researcher as controller and controlled students, were categorized by Ramos (2004) as passive and active. The passive students are those who only listen to the teacher and participate merely to clarify their own doubts about the topics. On the contrary, active students are those who express their opinions, ideas and feelings about the class activities.

The third category, Leaders are Necessary, evidenced that power relationships and leadership go hand in hand because generally leader students are the ones who have the power and command the practices within the classroom, are the most participative, almost always talk and control directly or indirectly the behavior of their classmates. But this dynamic is not bad at all, or at least it is not as bad as it sounds, because sometimes power exercised through the leadership is not only necessary but positive in order to accomplish the proposed task. There is a need to have leaders who propel the development of the activities. Thus, situations such as the accomplishment of the group task are affected by power relationships to the extent that if there is not a leader who has the power to control the members of the group, the task may not be attained completely. The bad side was that those leader students were always the same and the rest of the students did not take the risk of assuming the leadership role in any of the activities, so they were adopting an inactive role within their own learning process, which is quite negative. 
(Excerpt $\mathrm{N}^{\circ}$ 05. - Field Notes)

\begin{tabular}{|c|c|}
\hline Description & Researcher Analysis \\
\hline $\begin{array}{l}\text { March } 7^{\text {th }}-2016 \\
\text { Students are free to choose who to work with, so } \\
\text { they get together and start working without any } \\
\text { problem. The students who lead each group are } \\
\text { the same ones who have lead in previous oppor- } \\
\text { tunities. This is evidenced when they start the } \\
\text { brainstorming of ideas to be written in the pro- } \\
\text { posal, the leaders start giving ideas and the rest } \\
\text { of the group listen and agree with them. There } \\
\text { are some groups which do not have a clear lead- } \\
\text { er. }\end{array}$ & $\begin{array}{l}\text { The groups which did not have a clear } \\
\text { leader were less dynamic when work- } \\
\text { ing, they spent more time completing } \\
\text { the task and sometimes got distracted } \\
\text { and did things different from the task } \\
\text { at hand. Those groups did not have a } \\
\text { person who "pressures" them to start } \\
\text { working judiciously. }\end{array}$ \\
\hline
\end{tabular}

As could be seen in the previous excerpt, the groups who had a leader did not have problems in the attainment of the task. On the contrary those groups which lacked a leader had difficulties getting the task done. Leader students acquired certain responsibilities and roles within the groups they belonged to and made the groups work.

The fourth category, negative attitudes facing the task, showed certain situations which did not allow students to work together or to accomplish the task. One of those situations was that sometimes when the groups were distributed at random, students refused to work with the classmates they were assigned. The first time this happened students even got into conflicts and were rude with each other because of this situation. Another negative situation was the fact that some students were constantly afraid of performing in front of the group; they argued that pressure from their classmates was the main obstacle which did not let them to pass in front. They were afraid of making mistakes and they got very nervous because the class might bully them.

(Excerpt $\mathrm{N}^{\circ}$ 07. - Focused Interview March 4th-2016

T: ...hubo una situación en esa clase en particular...no sé si la recuerden, un grupo que definitivamente no pudo trabajar. [There was a situation in this class... I don't know if you remember, a group that could not work.

St. 08: si, si, ya sé cuál. [yes, yes I know which one]

T: ¿Por qué creen que ocurrió esa situación? [Why do you think this situation happened?]

St. 05: si, si, el de Pepito, Paquito y Pablito... a mí me tocó traerme a Pepito para mi grupo porque se caen súper mal con Paquito y Pablito; también Paquito con Pablito se caían súper mal todos con todos en ese grupo, no se la llevan para nada, nunca se la han llevado. [yes, yes, Pepito's, Paquito's and Pablito's... I had to join Pepito to my group because they do not like each other, Pepito and Pablito. Also Pepito and Pablito don't 
like each other, everybody in this group, they don't each other]

T: y si no se la llevan, como tú dices, ¿no hay posibilidad alguna de que trabajen juntos? [and if you don't like each other, as you say, is there a possibility to work together one day]

St. 05: pues no porque ahí la enemistad pesa más, ellos no se sentarían juntos ni porque pierdan la materia, o sea no... no, no cuadran para nada, ahí la profe hizo bien en cambiarlos. [No, because enmity is stronger, they can't sit down together non missing the subject, it is not possible, they do not match. The teacher did good when changed them.]

From the example above it could be inferred that students were upset when they had to work with partners different from their friends because they felt more powerful when they worked with their group of close friends rather than when they had to work with other classmates. The fact that they had to work with partners they usually did not share with makes many students feel uncomfortable and it sometimes caused trouble within the group. When they were out of their groups they experienced what Cummins (2000) denotes as coercive power. Coercive power relations refer to the exercise of power by a dominant individual or group to the detriment of a subordinated individual or group. Thus, coercive power has to do with oppression, domination, inequity and damage.
To conclude this category, it could be said that because of this coercive power, students sometimes felt scared to perform or talk in front of their classmates. When the teacher approached and asked them why they were afraid of completing oral tasks for example, they all argued that they had prepared and practiced but the pressure other students exercised over them was stronger so they felt very nervous and were not able to pass to the front of the class.

\section{Conclusions}

The first conclusion that can be drawn from this research is that it can be said that one of the aspects related to power relationships evidenced in the target group was the fact that having more or less power depended on how confident students were. Students with high self-confidence always got their classmates attention; they showed themselves to be powerful in front of their peers and exercised leadership in different activities and processes within the classroom. On the contrary students who evidenced a low selfconfidence level were the ones who did not participate, were always silent and preferred that other students take the floor in class.

The implementation of this research also led to proof that knowledge gives power. Most of the time students who had a higher English level were the ones who controlled the class. However other students in spite of their low English 
level, took the floor and participated because they knew about the class topic and they felt they could contribute, be active and give their opinions based on their knowledge about it.

It was also interesting to observe that students tried to keep control and power within the classroom according to their interests, motivations and abilities related to the subject and the activities developed in the class. For instance, some students led and controlled the class when they identified themselves with the topics discussed in class or when they had a higher English level than other students. On the contrary, when they lacked knowledge, they assumed less powerful positions, transferring the power to another classmate; in this way, power changed and circulated among students depending on the class's circumstances.

According to students' perceptions and some key issues observed, it could also be concluded that students feel more powerful when they work within their group of close friends rather than when they have to work with other classmates. The fact of meeting with partners they usually do not share with makes many students feel uncomfortable and sometimes it causes trouble within the group. Therefore, negative power relationships arise because some students like to have the control, and they commonly have it when they are with their friends. However, when they are asked to work with new classmates, they have to face a different situation, and some of them feel they lose power and control because they do not know how other students different from their close friends are going to react to their opinions and their actions at the moment of undertaking the development of the given task. Thus, being with their friends empowers them and their friends.

Students' perceptions about power exercised by them and their classmates showed that they consider the role and the image each student has within the group affect others' reaction to him/ her. If one student has a positive image in the group, he/she is more respected by his/her classmates, and hence has more power than a student who has a negative image or one whose image has not been projected to the group.

All these aspects related to power relationships sometimes helped and sometimes hindered the English language learning process. On the one hand, it could be evidenced how power relationships and leadership go hand in hand because generally leader students are the ones who have the power and command the practices within the classroom. These leader students are the most participative, the ones who almost always talk and the ones who control directly or indirectly the behavior of their classmates. Thus, situations such as the accomplishment of the group task are affected by power relationships to the extent that if there is no leader who has the power to control 
the members of the group, the task may not be completed.

On the other hand, a number of negative attitudes related to power relationships that affected certain situations within the class were identified. For instance, some groups of students refused to work together because they did not get along well with each other. Some students were emphatic about the impossibility of working with certain classmates they definitely do not sympathize with, so students did not obey teacher's orders concerning the distribution of the groups. Instead they just gave the teacher some other options and justified insistently the reasons they had to contradict the teacher's decisions.

\section{Pedagogical Implications}

When someone is immersed in a classroom and starts observing carefully what happens in it, an infinite number of issues can be perceived and some of these aspects may be positive while some others negative. Through this research, an exploration out of the aspects related to power relationships within an EFL classroom was conducted. An analysis of the implications of those power relationships have on the processes undertaken in the classroom showed that one key aspect in the success of the English language learning process is the classroom environment.

When students feel safe and comfortable within a classroom, they will surely be more motivated to learn and engage in the class activities. Additionally, if they are free to express their opinions without any fear, knowing that their classmates will respect what they think, most probably they will participate more actively and their learning process will be more effective.

When one student feels pressure because of his classmates' reactions and he knows that there are some students who control the class, he will possibly lose many opportunities to improve his skills and perhaps his motivation for learning will decrease.

This study focused its attention on a target group with several disciplinary and academic difficulties. During the diagnosis stage they showed coexistence problems which usually interfered with their academic results and their attitude in the English class. After working with them, through the workshops and when they were informed that they were selected to take part of a study (which may contribute to the improvement of their learning process), they felt important, they became involved in the development of the study and they slightly changed the attitude they had. They made themselves aware of the fact that, if they wanted to learn they had to improve the climate in which they shared every day by passing from a hostile classroom to a respectful and agreeable space. Their level of motivation for learning and doing the activities increased and their 
behaviors within the classroom were improving little by little.

While conducting this research study, the researcher perceived some aspects that deserved further research. For example, how can teachers, through their pedagogical practice, diminish school coexistence problems and contribute to the generation of more pleasant situations where all students can learn. Teachers-researchers can go beyond and analyze what aspects within their daily practices contribute to improve the classroom environment and students' learning.

Another important aspect that could be explored in future studies is how to strength those collaborative power relationships which produce positive effects on students' language learning processes. Important interventions could be addressed concerning this issue given that sometimes when the starting point is positive, results are expected to be positive too.

\section{References}

Brown, D., and Rogerts, J. (2002). Doing

Second Language Research. Oxford University Press.

Brown, R., and Gilman, A. (1960). The Pronouns of power and Solidarity. In T.A. Sebeok (ed), Style in Language, MIT Press. Corbin, J., and Strauss, A. (1990). Grounded theory research: Procedures, canons and evaluative criteria. Zeitschrift für Soziologie, 19(6), 418-427.

Cummins, J. (2000). Language, power and pedagogy. Bilingual children in the crossfire.
Clevedon: Multilingual matters. Cambrian printers Ltd. Great Britain.

Ellis, R. (2003). Task based language learning and teaching. New York: Oxford University Press.

Foucault, M. (1977). Discipline and punish: The birth of the prison system. Harmondsworth, England: Penguin.

Foucault, M. (1994). Power and Knowledge. Cambridge: Cambridge University press.

French. J., and Raven, B. (1959). The bases for social power. In D. Cartwright (Ed.), Studies in social power. Ann Arbor. Michigan: University of Michigan Press.

Johnson, D. (1979). Student-student interaction: The neglected variable in Education. University of Minnesota. Longman.

Long, M. (1983). Native speaker/nonnative speaker conversation and the negotiation of comprehensible input. Applied Linguistics, 4, 126-141.

Maxwell, J. (2009). Teamwork 101: What Every Leader Needs to Know. Yates and Yates. United States of America.

Ortega, H. (2005). Poder y Práctica Pedagógica. Cooperativa Editorial Magisterio. Colección Seminarium. Bogotá, Colombia.

Ramos, B. (2004). Power Relation in the EFL class through oral interaction (Master's thesis). Universidad Distrital Francisco José de Caldas, Bogotá.

Richmond, V., and McCroskey J. (1992). Power in the classroom: Communication, control and concern. Lawrwnce Erlbawn Associates, Inc. 
Rosemary, S. (2004). The power of language (chapter). Thoughts and actions. In The NEA higher education journal.

Tannen, D. (1995). The power of talk: Who gets heard and why. Harvard Business Review, 73(5), 138-148.

Toohey, K. (2001). Disputes in child L2 Learning. TESOL Quarterly, 35, 257-278.

Wilson, B. G. (1996). Constructivist learning environments: case studies in Instructional design. Englewood Cliffs NJ Educational Technology publications.

Yin, R. K. (2009). Case Study in Contemporary Educational Research: Conceptualization and Critique. Cross Cultural communication. 5 (4), 21-31. 